\title{
Holocene history of human impacts inferred from annually laminated sediments in Lake Szurpiły, northeast Poland
}

\author{
Małgorzata Kinder (D) - Wojciech Tylmann • Iwona Bubak • Magdalena Fiłoc • \\ Michał Gạsiorowski • Mirosława Kupryjanowicz • Christoph Mayr • \\ Laurentius Sauer • Ulrich Voellering • Bernd Zolitschka
}

Received: 3 July 2018/ Accepted: 14 January 2019/Published online: 13 February 2019

(C) The Author(s) 2019

\begin{abstract}
Annually laminated lake sediments provide high-resolution and accurate timescales for reliable paleoenvironmental reconstructions. We investigated human activity in a low-human-impact region of Poland, taking advantage of varved sediments from Lake Szurpiły, which span the last 8200 years. Multiple sediment variables indicated that catchment evolution and lacustrine responses, mainly to changes in forest cover, were divided into four phases. Because of sparse or only seasonal occupation of settlements in NE Poland, human impact in the region was insignificant until ca. $939 \pm 55$ BC (lacustrine phase I). During Phase II
\end{abstract}

M. Kinder $(\square) \cdot$ W. Tylmann

Environmental Change Reconstruction Laboratory, Faculty of Oceanography and Geography, University of Gdańsk, Gdańsk, Poland

e-mail: malgorzata.kinder@ug.edu.pl

W. Tylmann

e-mail: wojciech.tylmann@ug.edu.pl

\section{Bubak}

Department of Hydrology, Faculty of Oceanography and Geography, University of Gdańsk, Gdańsk, Poland

e-mail: iwona.bubak@ug.edu.pl

M. Fiłoc · M. Kupryjanowicz

Department of Paleobotany, Institute of Biology,

University of Białystok, Białystok, Poland

e-mail: m.filoc@uwb.edu.pl

M. Kupryjanowicz

e-mail: m.kupryjanowicz@uwb.edu.pl
$(939 \pm 55 \mathrm{BC}-\mathrm{AD} 1392 \pm 38)$, we recorded an increase in human indicators, reflecting the direct influence of a Yatvingian community. Afterwards, between AD $1392 \pm 38$ and $1770 \pm 30$ (phase III), permanent settlements and agricultural land use stabilized. The beginning of the last period (phase IV) was clearly identified by all sediment variables, which responded simultaneously to local human activities. Disappearance of laminae from AD $1858 \pm 22$ until about AD 1997 indicated disturbance of pre-existing, stable depositional conditions, followed by environmental recovery in the last 20 years. Such recovery may have been related to recent socio-economic

\footnotetext{
M. Gąsiorowski

Institute of Geological Sciences, Research Centre in Warsaw, Polish Academy of Sciences, Warsaw, Poland e-mail: mgasior@twarda.pan.pl

C. Mayr · U. Voellering

Institute of Geography, Friedrich-Alexander Universität

Erlangen-Nürnberg, Erlangen, Germany

e-mail: christoph.mayr@fau.de

U. Voellering

e-mail: ulrich.voellering@fugmannjanotta.de

C. Mayr · L. Sauer

Department of Earth and Environmental Sciences,

Ludwig-Maximilians-Universität München, Munich,

Germany

e-mail: laurentius.sauer@yahoo.com
} 
changes and establishment of a park that reduced human influence on the lake.

Keywords Varved sediments - Biological proxies . Geochemistry $\cdot$ Environmental reconstruction .

Human impact · Holocene

\section{Introduction}

Lake sediments are valuable sources of information about human impacts on the Earth system during the Anthropocene (Berglund 2003; Messerli et al. 2000). Lacustrine sediments reflect processes both within and outside the lake, including local and regional human activities. Therefore, lake sediments are considered to be excellent archives for paleoenvironmental research (Cohen 2003). Annually laminated (varved) lake sediments are of special interest because they represent annual cycles of deposition and possess multiple variables that can be used as proxies of past climate and environmental conditions (Zolitschka et al. 2015). Identification of human impact on the environment during the last few millennia is fundamental to better understand mechanisms of change and to model future scenarios (Dearing 2006; Mills et al. 2017). Varved lake sediments can be used to track human-induced disturbances in ecosystems, such as the history of lead pollution (Stanton et al. 2010), fluctuations in lacustrine productivity (Dreibrodt and Wiethold 2015) or changes in erosion intensity (Augustsson et al. 2013), at high resolution, i.e. at annual or even seasonal timescales.

Despite the large number of long records from Central Europe of natural environmental fluctuations and human impacts, there is still a need for more interdisciplinary paleoenvironmental reconstructions supported by accurate, high-resolution dating (Berglund 2003; Dubois et al. 2018). Northeastern Poland is unique in terms of geographical position, richness in freshwater sediment archives and settlement history

\section{B. Zolitschka}

Geomorphology and Polar Research (GEOPOLAR), Institute of Geography, University of Bremen, Bremen, Germany

e-mail: zoli@uni-bremen.de
(Engel and Sobczak 2012). Each human settlement period left traces in the catchments of lakes, which are detectable using appropriate methods. The chronological framework for paleoecological reconstructions from this and neighboring regions is based mainly on radiocarbon dates (Gałka et al. 2014; Stivrins et al. 2016; Szal et al. 2017). The timescales for such studies thus depended on results of age-depth modeling, and their resolution is relatively poor. Lakes in this area, recently discovered to possess varved sediments, provide ideal archives for paleoenvironmental reconstructions (Tylmann et al. 2013), tracking humaninduced erosion and increased terrigenous inputs to lakes (Bonk et al. 2016; Poraj-Górska et al. 2017). The advantage of these natural archives is the quality and long time span represented by their laminated sediments, compared to deposits from other regions. Bonk et al. (2016) and Poraj-Górska et al. (2017) reported on records spanning relatively short time periods of only 1000 and 200 years, respectively. Radiocarbon dates on terrestrial plant remains are commonly used to generate sediment chronologies for paleoenvironmental studies, e.g. Lake Linówek (Gałka et al. 2014), but varved sediment sequences provide much higher temporal accuracy and resolution. Moreover, varves themselves provide important information about depositional processes, i.e. annual sedimentation rates and seasonal fluctuations.

Archeological investigations from the Suwałki region, where Lake Szurpiły is located, provide information about human settlement from the Mesolithic (8000-4500 BC) to historic times (Antoniewicz 1965; Engel and Sobczak 2012). The geographic extent and magnitude of the impacts of these settlements on local environments, however, is not known. We used the varved sediment archive from Lake Szurpily to establish precisely the timing of first human impact in the region, and to track the consequences of increasing human activity on the lake environment through time.

Our general goal was to infer human-induced paleoenvironmental changes using the 8200 -year-long sediment record from Lake Szurpiły. We took full advantage of the well-preserved biogenic varves in the sequence, using multiple sediment variables and complementary analyses in our study. The pollen record was used to track deforestation and agriculture, which transformed the catchment, whereas analyses of diatoms, cladocerans, sedimentology, element 
geochemistry and stable isotopes enabled us to track lacustrine processes that responded to changing human impact. Our results relied on the varve chronology of Kinder et al. (2013) and are compared with other data. We focused on: (1) anthropogenic transformation of local vegetation; (2) multi-proxy evidence of human impact on sedimentation; (3) timing of distinct changes in the catchment and lake.

\section{Study site}

Lake Szurpiły is located $183.1 \mathrm{~m}$ a.s.l. in the Suwałki Lake District, northeast Poland $\left(22^{\circ} 53.5^{\prime} \mathrm{N}\right.$, $54^{\circ} 13.8^{\prime} \mathrm{E}$ ) (Fig. 1). Topography of the area developed during the Pomeranian Phase of the Weichselian glaciation, with considerable influence of glaciotectonic processes (Ber 2000). The lake catchment has a surface area of $11.14 \mathrm{~km}^{2}$ and is dominated by Quaternary glacial sand, gravel and till (BajkiewiczGrabowska 1994). The lake basin formed during the Allerød (Kupryjanowicz, unpublished pollen data) as a result of dead-ice melting and damming of the
Szeszupa depression by frontal moraines. The lake has a surface area of $0.81 \mathrm{~km}^{2}$ and a maximum water depth of $46.2 \mathrm{~m}$ (Fig. 1). Today, Lake Szurpiły is fed by two periodic inflows, and has one outflow in the northeast. The lake is classified as dimictic and eutrophic, with hypolimnetic anoxia during periods of summer and winter stratification (Górniak et al. 2007).

A temperate and continental climate prevails in the study area, with a mean annual air temperature of $6.5^{\circ} \mathrm{C}$ (Lorenc 2005). Climate conditions are mainly a consequence of long and cold winters, and relatively long distances to the Atlantic Ocean and Baltic Sea, which makes this region one of the coldest in Poland. These conditions are reflected by the vegetation and probably affected the human settlement history in the past few millennia. Modern human impact is limited by the presence of Suwałki Landscape Park, but the lake catchment is dominated by arable land (Fig. 1c). Forests cover only $10 \%$ of the area (BajkiewiczGrabowska 1994).

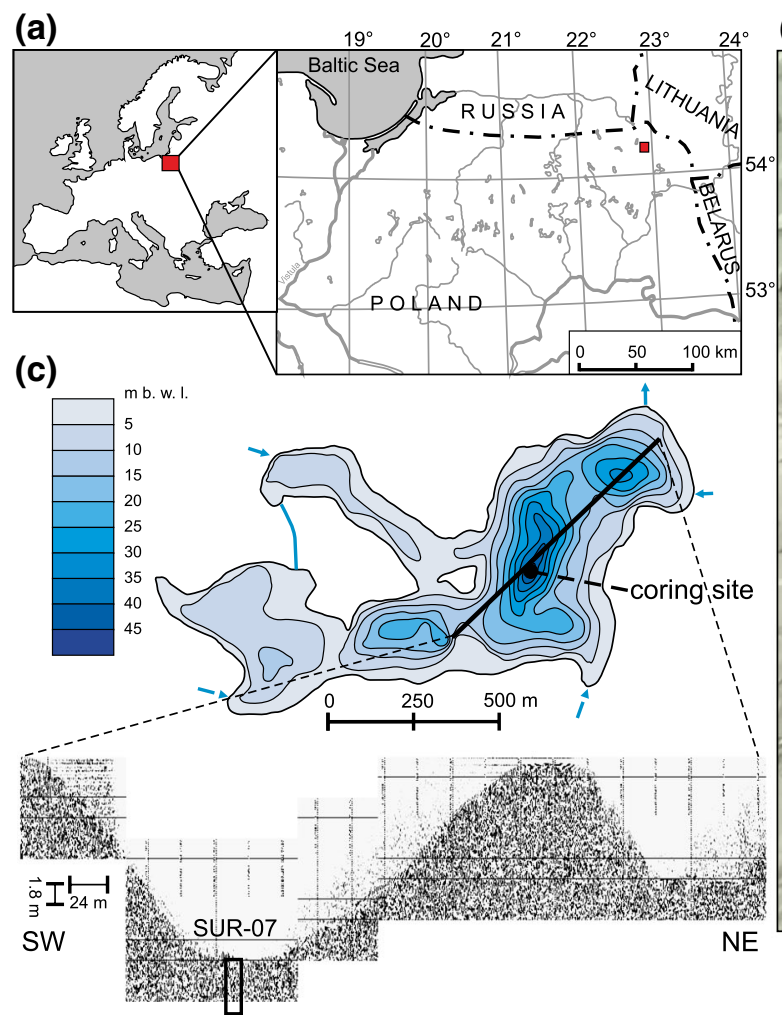

(b)

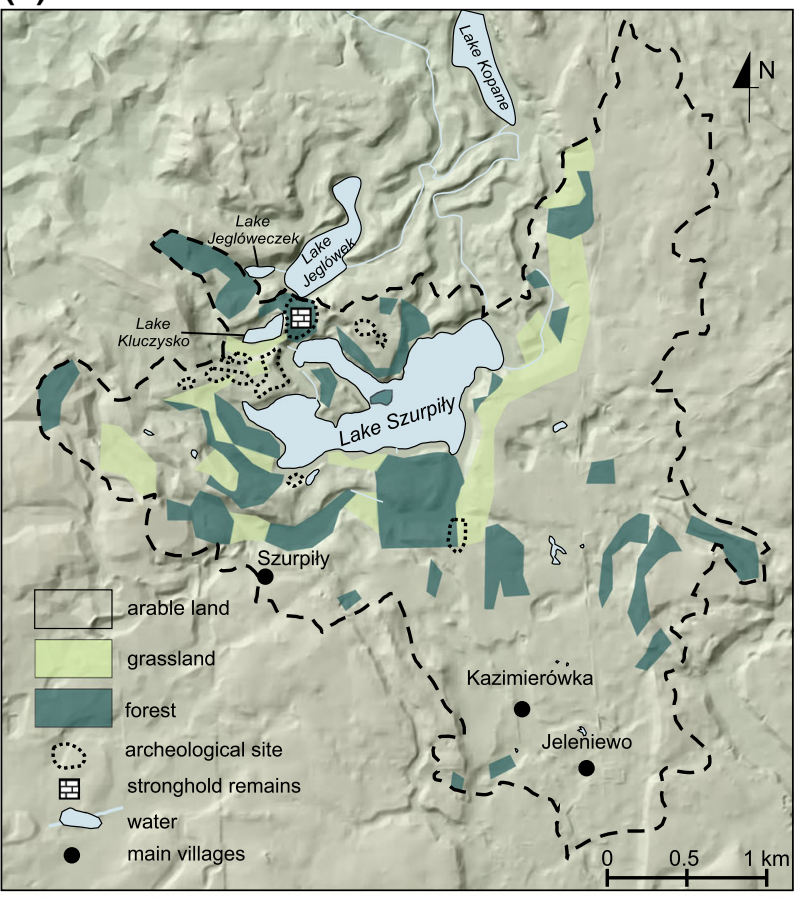

Fig. 1 a Location and $\mathbf{b}$ characteristics of the modern Lake Szurpiły catchment, $\mathbf{c}$ bathymetric map and seismic profile with coring site (SUR-07) indicated 
Archeological studies, particularly the Multidisciplinary Yatvingian Expedition initiated by a group of scientists in the 1960s, and renewed research in the last few years (Bitner-Wróblewska et al. 2016; Engel and Sobczak 2012), provided evidence of local human activities in the past (Fig. 1b). The areas surrounding Lake Szurpiły were sparsely or only seasonally inhabited during the Mesolithic (8000-4500 BC) and Neolithic (4500-1800 BC) (Antoniewicz 1965). Most of the archeological sites date to the Middle Ages (especially to the 12th-13th century), when a stronghold developed near three of the lakes (Szurpily, Kluczysko and Jeglówek), in the central part of Yatvingia. The stronghold was conquered by the Teutonic Knights in AD 1283 (Engel and Sobczak 2012). The following 150 years are known as the period of 'tribal emptiness', yet there was a small, hidden population in the forests (Antoniewicz 1965). Camaldolese monks settled near Lake Wigry $(25 \mathrm{~km}$ SE of Lake Szurpily) in AD 1667 and recolonized surrounding lands. In AD 1705, the remains of the stronghold were referred to Surpilańska Góra, indicating a withdrawal from the settlement (Antoniewicz 1965).

Economic recovery followed the Congress of Vienna in $\mathrm{AD}$ 1815, when the Kingdom of Poland was established. The political situation in the 20th century resulted in socio-economic changes in NE Poland. These included, among others, resettlement after the Second World War and reorganization of agriculture after AD 1989. New factories provided employment for inhabitants in the 1970s. Establishment of the Suwałki Landscape Park in AD 1976 limited human impact mainly to agricultural and touristic activities.

\section{Materials and methods}

Sediment coring, chronology and correlation

In September 2007, sediment cores were retrieved from a floating platform over the deepest part of the lake (46.2 m water depth), using a gravity corer and the UWITEC piston coring system (Kinder et al. 2013). The composite sediment profile (total length: $12.39 \mathrm{~m}$ ) was constructed by visual correlation of gravity core SUR07/2 and two overlapping piston cores (SUR07/5 and SUR07/8). There is a turbidite layer at 9.28-7.58 m sediment depth, but only the undisturbed and precisely dated upper part of the record was used for this study. The age-depth model was established using the varve chronology, supported by ${ }^{210} \mathrm{~Pb}$ dating and verified by $14 \mathrm{AMS}{ }^{14} \mathrm{C}$ dates on selected terrestrial macrofossils. Detailed descriptions of the methods used to develop the chronology, conduct varve measurements and calculate mass accumulation rate (MAR), were published by Kinder et al. (2013). All dates are expressed in years BC/AD to facilitate comparison with archeological and historic data.

\section{Pollen}

Pollen samples were extracted at 8 -cm intervals throughout the core. Standard laboratory treatment and Erdtman acetolysis was applied to $1-\mathrm{cm}^{3}$ samples (Faegri and Iversen 1989). The mineral fraction was separated by heavy liquid flotation (KI + CdI solution, $\rho=2.1 \mathrm{~g} \mathrm{~cm}^{-3}$ ). Lycopodium spore tablets were added to the samples to enable calculation of pollen concentrations (Stockmarr 1971). Approximately 1000 terrestrial pollen grains, pollen and non-pollen palynomorphs (NPP) were identified in each sample.

\section{Diatoms}

Samples of $1 \mathrm{~cm}^{3}$ were taken at $8-\mathrm{cm}$ intervals and prepared following standard procedures (Battarbee 1986) and mounted in Naphrax ${ }^{\mathrm{TM}}$. Five hundred valves were counted in each sample and relative abundances of taxa were calculated. Diatom ecological taxonomy followed common classifications (Hustedt 1956; Round 1981) and ecological indicator values for individual taxa (Hofmann 1994).

\section{Cladocera}

Material for cladoceran analysis was prepared according to Frey (1986). Samples ( $1 \mathrm{~cm}^{3}$ of fresh sediment) were treated with $10 \% \mathrm{HCl}$ to eliminate carbonates, followed by $10 \% \mathrm{KOH}$ to remove humic matter. After each treatment, the residue was washed with distilled water and sieved using a $40-\mu \mathrm{m}$ sieve. A measured volume of the final residue was stained with safranine, sub-sampled quantitatively and mounted on a microscope slide. Enumerated remains included shells, 
headshields, postabdomens, postabdominal claws, and ephippia.

\section{Geochemistry and stable isotopes}

We analyzed sediment lithology and aspects of sediment chemistry related to lake productivity. Loss-on-ignition at $550{ }^{\circ} \mathrm{C}$ for $4 \mathrm{~h}$ was used to estimate organic matter (OM) content (Heiri et al. 2001). Total organic carbon (TOC), total inorganic carbon (TIC) and total nitrogen (TN) were analyzed at 8-cm resolution with a CNS analyzer (Euro-EA, HEKAtech $\mathrm{GmbH}$ ). An alkaline leaching method (Müller and Schneider 1993) was used to determine biogenic silica (BSi). Minerogenic matter (MM) was calculated by subtraction from the total mass of OM, $\mathrm{BSi}$ and $\mathrm{CaCO}_{3}$, the latter estimated by multiplying TIC by 8.33 (Dean 1999). Iron and manganese counts were determined by XRF (X-ray fluorescence) scanning at the GEOPOLAR laboratory (University of Bremen) using an ITRAX Core Scanner with 5-mm resolution.

For $\delta^{15} \mathrm{~N}$ determination, bulk sediment was weighed into tin capsules and combusted at $1060{ }^{\circ} \mathrm{C}$ in an element analyzer (Carlo Erba NC2500) linked to an isotope ratio mass spectrometer (Thermo-Finnigan DeltaPlus). Carbon isotope ratios of bulk organic matter $\left(\delta^{13} \mathrm{C}_{\text {org }}\right)$ were determined on samples decalcified with $\mathrm{HCl}(5 \%)$ for $6 \mathrm{~h}$ in a water bath at $50{ }^{\circ} \mathrm{C}$. Analyses were carried out with the same system as for nitrogen. Isotope ratios of an element (E) are reported as $\delta$ values in \%o according to the equation $\delta \mathrm{nE}=\left(\mathrm{R}_{\text {sample }} / \mathrm{R}_{\text {standard }}-1\right) \times 1000$, with $\mathrm{R}_{\text {sample }}$ and $\mathrm{R}_{\text {standard }}$ as isotope ratios $\left({ }^{13} \mathrm{C} /{ }^{12} \mathrm{C},{ }^{15} \mathrm{~N} /{ }^{14} \mathrm{~N}\right)$ of the sample and international standards (VPDB for carbon, AIR for nitrogen), respectively, with $\mathrm{nE}$ being the heavy isotope $\left({ }^{15} \mathrm{~N},{ }^{13} \mathrm{C}\right)$ of the respective element.

\section{Data analysis}

Multivariate methods were performed for the datasets to identify underlying relationships and facilitate interpretation. Because of the different sample spacing used for analyses ( $0.5 \mathrm{~cm}$ for XRF, $8 \mathrm{~cm}$ for CNS), the resolution was standardized to $8 \mathrm{~cm}$ by selecting the samples from consistent depths for each variable to make the datasets comparable. Higher resolution in the upper part of the record is apparent because results are plotted versus time. Diatom and cladoceran taxa were retained in statistical analyses if their abundance was $\geq 2 \%$ in at least one sample. The requirement for pollen taxa was $\geq 1 \%$ abundance in at least one sample. Data were standardized with the vegan package in $\mathrm{R}$ (Oksanen et al. 2018). The Hellinger transformation was applied to biological variables. Because stable isotope data are negative, a constant value was added $(\mathrm{x}+1-\min (\mathrm{x}))$ prior to $\log$ transformation of the isotope values.

Clustering was applied to the geochemical, isotope, diatom, cladoceran and pollen data. Stratigraphically constrained hierarchical clustering was performed using the RIOJA package (Juggins 2017) in R ( R Core Team 2013). We selected Euclidean distance and the CONISS (Ward's) agglomeration method as a dissimilarity matrix and linkage method, respectively (Hammer and Harper 2006). The number of significant clusters was determined with the broken stick model. A separate clustering was made for the reduced multiproxy dataset, which represents the lake response to environmental changes. We used diatom and cladoceran groups, as well as the Eubosmina (including Bosmina coregoni, B. reflexa and B. longispina) to Bosmina ratio, MAR and the first three significant principal components of the geochemical dataset. Diatoms were grouped according to their ecological (trophic and $\mathrm{pH}$ ) preferences, whereas cladocerans were assigned to four habitat groups based on Bjerring et al. (2009). We used the rda function of the vegan library in R (Oksanen et al. 2018) to perform principal component analysis (PCA) to examine the major patterns within the geochemical dataset and the correlation between variables. Redundancy analysis (RDA) was conducted to relate the pollen data (explanatory variables) to the lacustrine response variables. Computations and plotting were performed in $\mathrm{R}$ using vegan $2.5-2$ and ggvegan $0.0-9$ packages (Simpson 2017). The significance of RDA axes was assessed with permutation tests using the anova function with 999 permutations.

\section{Results}

Sediment lithology, varve thickness and mass accumulation rate

The composite profile is dominated by annually laminated, carbonate-rich and organic-carbonate 
Fig. 2 Basic features of the sediment profile with slump deposits (triangles), varve thickness (raw values and 11-year running mean), MAR - mass accumulation rate (raw values and 11-year running mean), light/darkspring-summer to fallwinter laminae thickness ratio

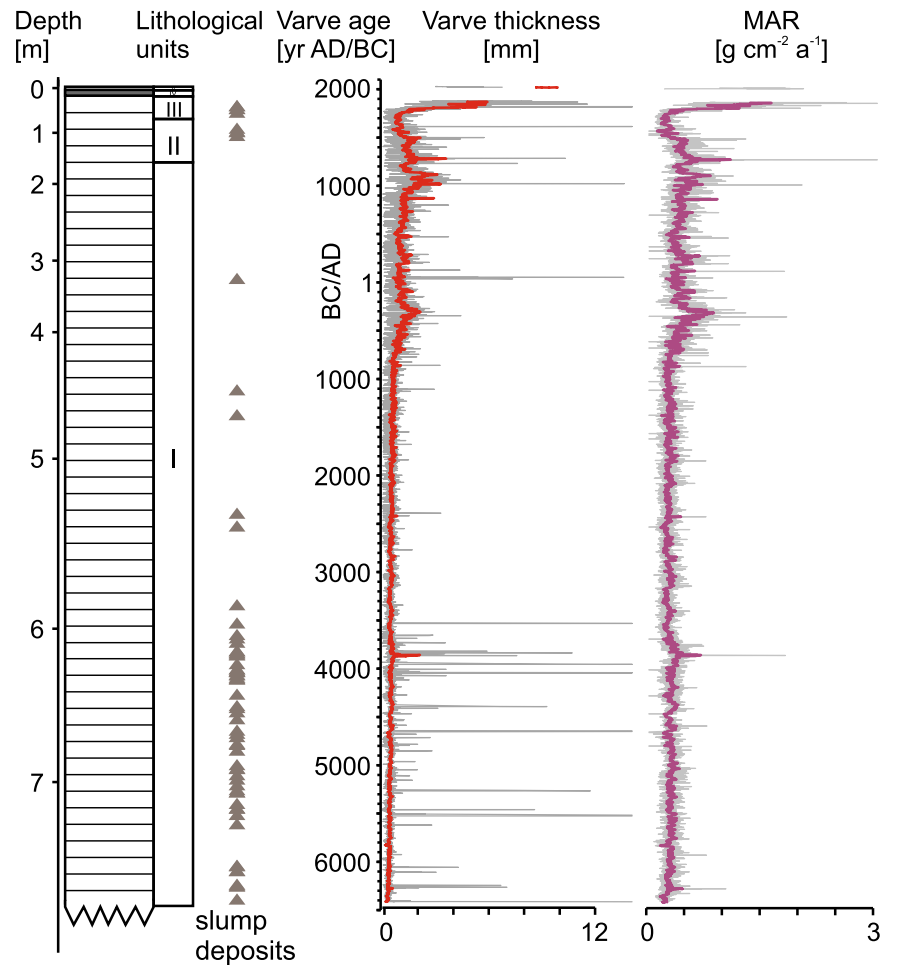

Light /dark laminae

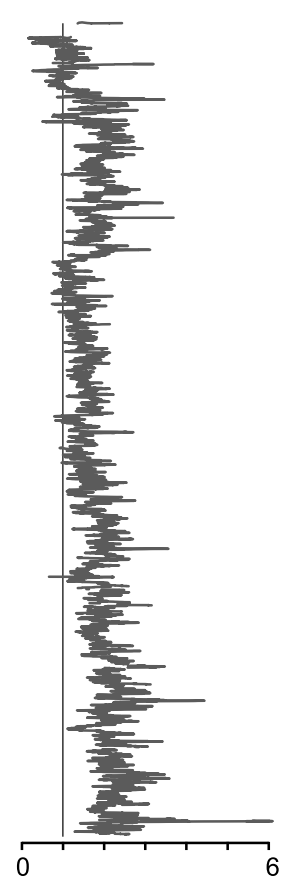

gyttja, in some sections disturbed by small-scale slump deposits (Fig. 2). Five lithological units were distinguished macroscopically. In SUR-07-I (7.53-1.50 m, $6253 \pm 94$ BC-AD $1522 \pm 38)$ and SUR-07-II (1.50-0.71 m, AD $1522 \pm 38-1793 \pm$ 30), finely laminated carbonaceous gyttja is present, with some variations. A distinctly greater mean varve thickness is noted around 350 BC and AD 1000-1100, whereas relatively stable, low thicknesses prevail between AD 1550 and 1750. Unit SUR-07-III $(0.71-0.28 \mathrm{~m}, \mathrm{AD} 1793 \pm 30-1858 \pm 22)$ is characterized by greater and irregular varve thickness ( 1.3-12 mm). SUR-07-IV (0.28-0.08 m, AD $1858 \pm 22-1997)$ is a non-laminated sequence. Since AD 1998 (SUR-07-V, 0.08-0.0 m), laminated organic-carbonaceous gyttja appears again.

The mean mass accumulation rate (MAR) was $0.33 \mathrm{~g} \mathrm{~cm}^{-2} \mathrm{a}^{-1}$, with a standard deviation (SD) of 0.18 . A distinct increase, reaching $1.8 \mathrm{~g} \mathrm{~cm}^{-2} \mathrm{a}^{-1}$ appeared at $4 \mathrm{~m}$ depth (ca. $500 \mathrm{BC}$ ) (Fig. 2). The stability of MAR was interrupted by 68 subaquatic, mass movement deposits. SUR-07-I contains 60 slump layers, most of which occurred between approximately 5500 and 3500 BC. They reappeared occasionally in SUR-07-II and SUR-07-III (four in each unit) after relatively undisturbed sedimentation conditions. None of the slump deposits had a coarse bottom, suggesting either local relocation within the lake basin or the distal side of a larger structure having its origin on the slopes of the neighboring moraines. Moreover, the fine-grained and relatively thin mass movement layers had a low erosive influence. SUR-07-IV does not possess any structures, neither varves nor mass movement deposits. Uppermost unit SUR-07-V is continuously annually laminated and undisturbed.

Although spring-summer (light) laminae dominate the annual varve thickness, the internal structure of varves varies throughout the profile, as shown by changes in the light-to-dark lamina ratio (Fig. 2). A decreasing trend is recorded between 7.53 and $4.0 \mathrm{~m}$ (ca. 6250-550 BC), whereas higher MAR values after $550 \mathrm{BC}$ resulted mainly from thicker fall-winter laminae.

Biogenic variables

Results of analysis of selected variables are informative about changes in the catchment area and Lake Szurpiły during the last 8200 years (Figs. 3, 4). Zone 


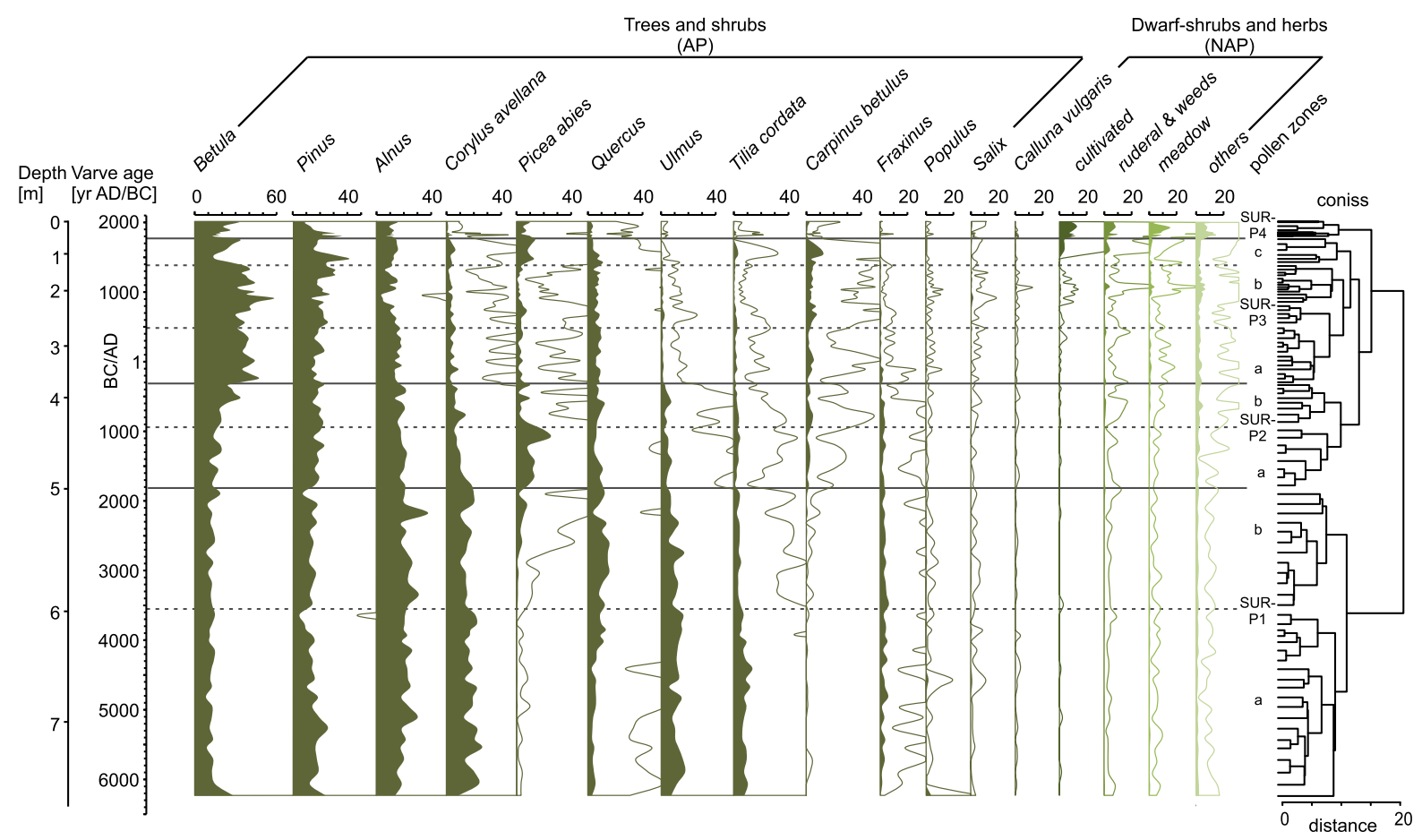

Fig. 3 Simplified pollen percentage diagram (unshaded areas show a $10 \times$ exaggeration) and results of cluster analysis with pollen zones SUR-P1 to SUR-P4

boundaries reported are the median age $\mathrm{BC} / \mathrm{AD}$ of adjacent samples.

\section{Pollen}

A total of 102 pollen taxa were encountered, among which 28 species reached an abundance of $1 \%$ in at least one sample. Four main pollen zones, reflecting the terrestrial vegetation, were identified (Fig. 3). Arboreal pollen (AP) grains generally dominated (93\% on average) throughout the sediment profile (Fig. 5). Non-arboreal pollen (NAP), however, increased significantly during the last 500 years ( $>40 \%$ abundance). The first, bipartite zone (SUR$\mathrm{P} 1,6253 \pm 94-1851 \pm 64 \mathrm{BC}$ ) is characterized by the highest percentages of Alnus (up to 37.6\%). The second most dominant is the light-demanding shrub Corylus avellana (17\% mean, 25.9\% max.), followed by Betula and Pinus. The highest percentages of thermophilic trees Ulmus and Tilia cordata are also observed in the zone. There are, however, decreasing trends in relative abundance of these taxa in comparison with increasing abundances of Picea abies (enabling division into two subzones) and Quercus.
SUR-P1 possesses negligible NAP or human disturbance indicators. Zone SUR-P2 (1851 \pm 64 $326 \pm 50 \mathrm{BC}$ ) consists of two sub-zones divided by a decrease in Picea abies and an increase in Betula and ruderal and weed taxa. SUR-P2 is dominated by Betula (max. 33.4\%), with secondary contributions from Pinus, Alnus and Picea abies, which reached a maximum abundance of $24.6 \%$ at $1105 \pm 57 \mathrm{BC}$. A decline in $\mathrm{AP}(771 \pm 55 \mathrm{BC})$ and more frequent pollen of cultivated plants reflects progressive changes in the catchment vegetation, however combined human activity indicators represent $<3 \%$. Dominance of Betula continues in zone SUR-P3 (326 \pm 50 BC$\mathrm{AD} 1770 \pm 30$ ) and reaches $58.1 \%$ at $\mathrm{AD} 903 \pm 42$. Division of this zone into three parts is defined by changes in indicators of human activities. The youngest sub-zone is marked by a decrease in Betula accompanied by the recovery of Picea abies. Calluna vulgaris fluctuations show forest disturbances, with a maximum at $\mathrm{AD} 1060 \pm 39$ and stabilization since AD $1522 \pm 37$. Human-indicator abundances rose substantially (up to $13.5 \%$ ) and revealed several settlement phases separated by periods of regeneration of the natural vegetation. Characteristic features of 

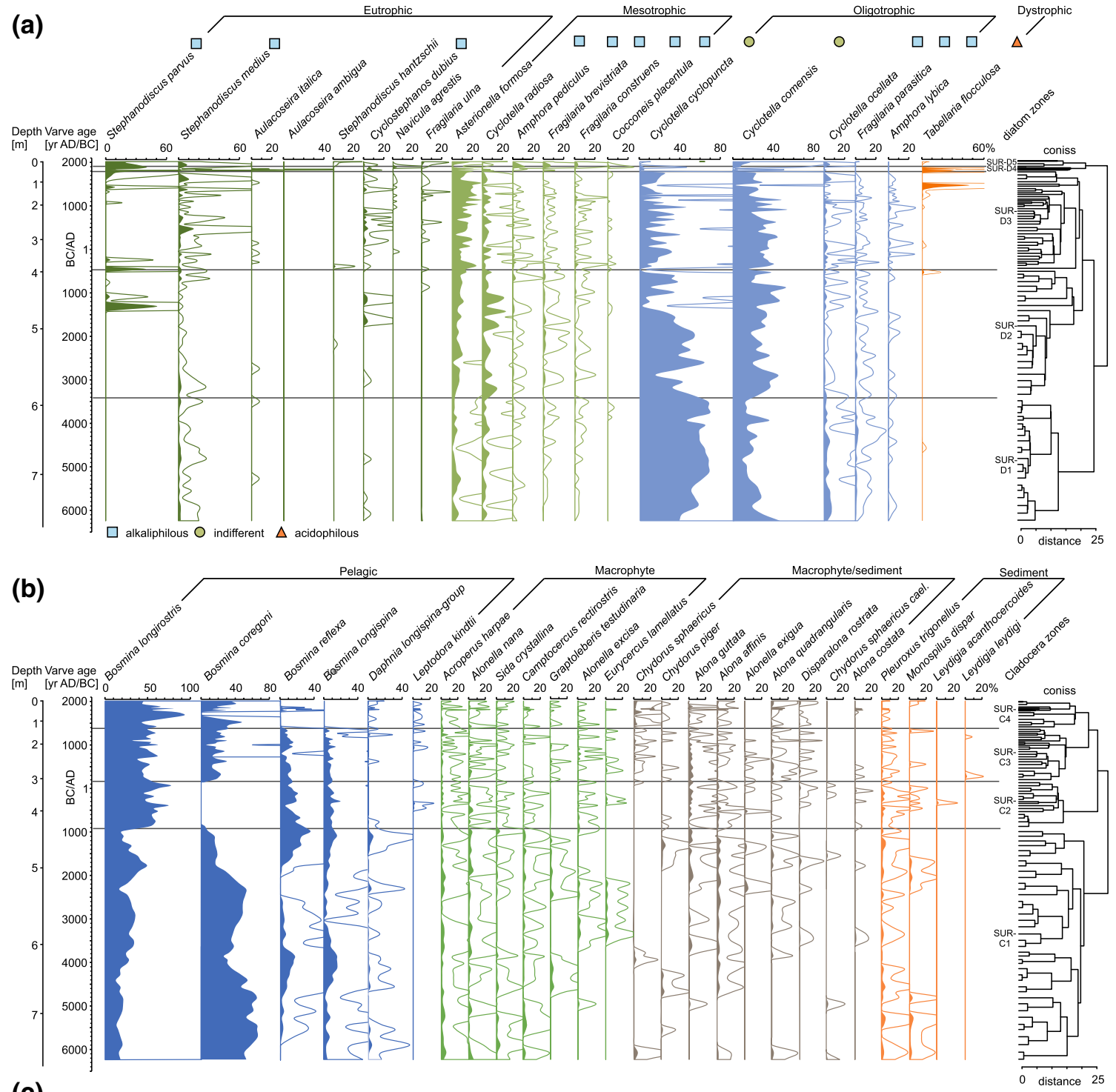

(c)

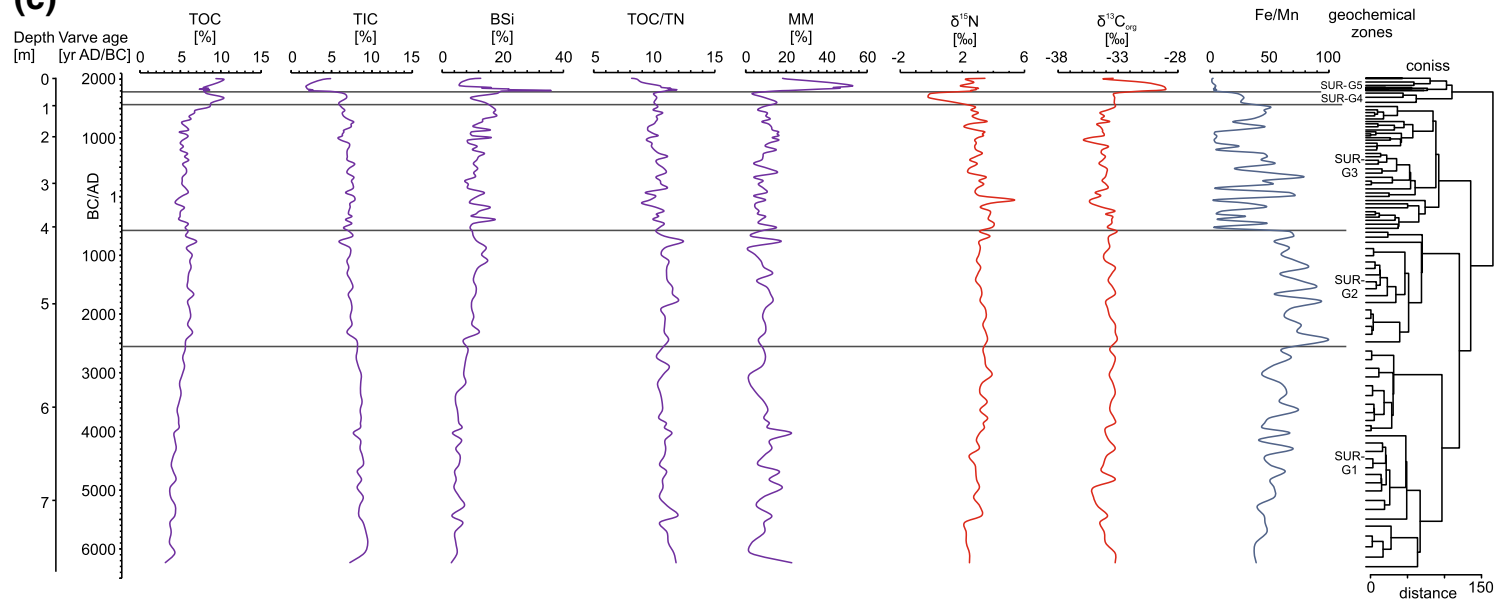


4Fig. 4 Multi-proxy diagrams and results of cluster analysis: a diatoms sorted by ecological groups, $\mathbf{b}$ Cladocera separated by habitat groups, $\mathbf{c}$ selected sediment components, geochemistry and stable isotopes

zone SUR-P4 (AD $1770 \pm 30-2006)$ are the most distinct changes in local vegetation and continuous presence of cultivated plants. A rapid increase in NAP, from 24.2 to $43.9 \%$, caused mainly by large-scale forest clearance and planting of cultivated taxa (up to $13 \%$ ), was followed by a sharp decline and recovery of trees (from 55.3 to $74.4 \%$ ) after $\mathrm{AD} 1936 \pm 10$.

\section{Diatoms}

One hundred and forty-two diatom taxa were identified, among which 20 species with clearly defined environmental preferences reached abundances of $2 \%$ in at least one sample (Fig. 4a). Five diatom zones were distinguished. Zone SUR-D1 $(6253 \pm 94-3436 \pm 70 \mathrm{BC})$ is dominated by oligotrophic, planktonic Cyclotella cyclopuncta and $C$. comensis, which together contribute up to $87 \%$. Asterionella formosa, Cyclotella radiosa and $C$. ocellata played minor roles (3\% mean each). In the second zone (SUR-D2, $3436 \pm 70-503 \pm 52 \mathrm{BC}$ ), $C$. comensis was partly replaced by $C$. cyclopuncta.
Moreover, mesotrophic species show increasing relative abundances with the dominance of $A$. formos $a$ and C. radiosa. A few peaks of eutrophic taxa (Stephanodiscus parvus, Cyclostephanos dubius) indicate short periods of higher trophic status. A second peak, together with the appearance of Tabellaria flocculosa, points to the transition to the next zone (SUR-D3, $503 \pm 52$ BC-AD $1770 \pm 30$ ), in which mesotrophic and eutrophic taxa gradually replaced oligotrophic indicators. The dystrophic and acidophilous species $T$. flocculosa occurred episodically, with a maximum abundance of $>30 \%$ at AD $1466 \pm 38$. The uppermost part of the sediment profile is divided into two diatom zones of short duration with less frequent oligotrophic species. Zone SUR-D4 (AD $1770 \pm 30-1862 \pm 20$ ) is characterized by dominance of eutrophic taxa, mainly $S$. parvus, Stephanodiscus medius, and A. formosa, accompanied by occasional peaks of Aulacoseira italica and A. ambigua (exceeding 30\%) and permanently high abundance of $T$. flocculosa (27.5\% mean), which may reflect soil erosion in the catchment. Diatom composition in the most recent zone SUR-D5 (since $\mathrm{AD} 1862 \pm 20$ ) is characterized by an increase in abundances of alkaliphilous S. parvus, Amphora pediculus and Fragilaria brevistriata, and a decrease in oligotrophic C. cyclopuncta.

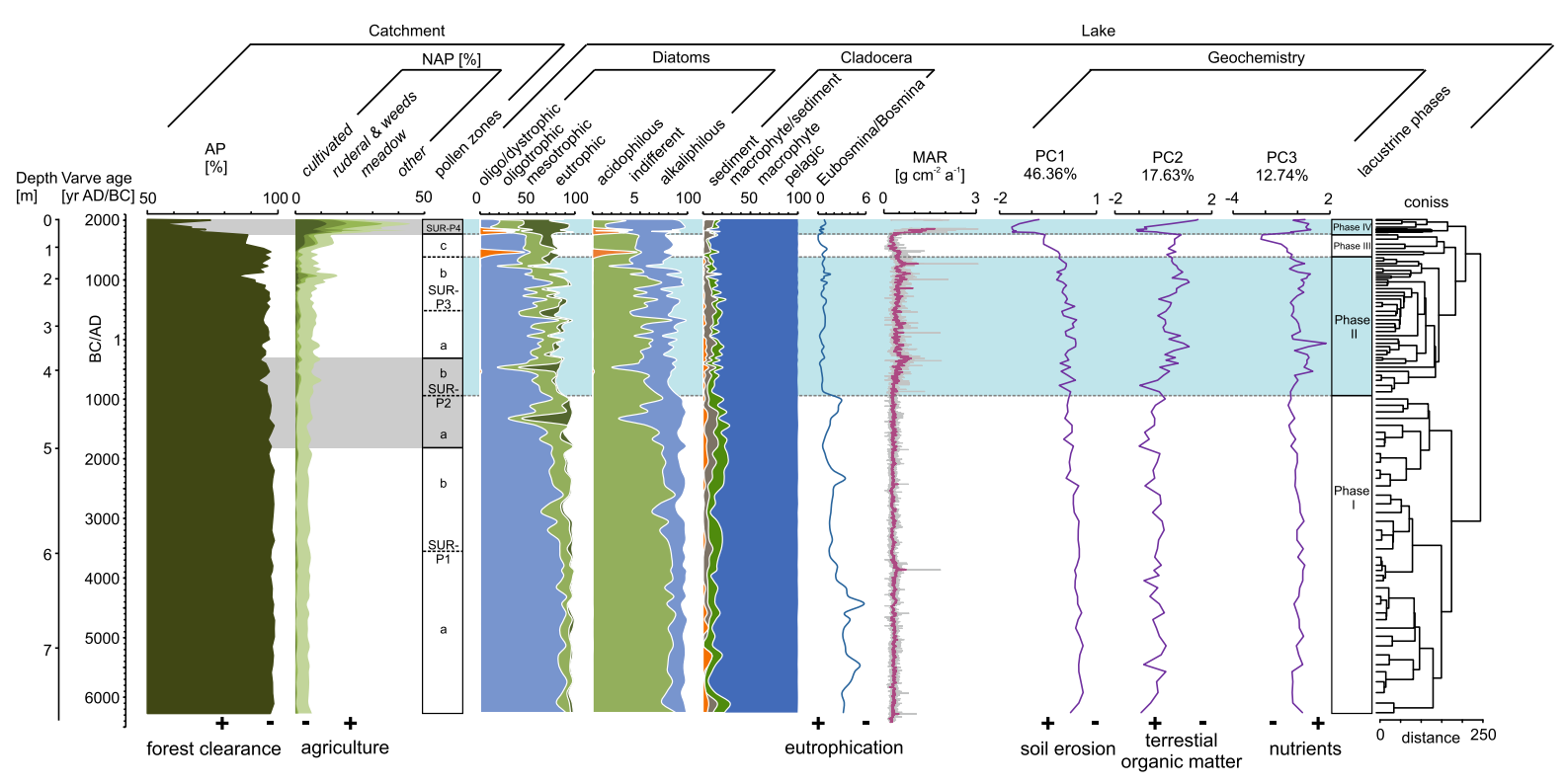

Fig. 5 Multi-proxy data integration representing the evolution of the catchment and Lake Szurpiły during the past 8200 years. The dendrogram is based on the combined diatom, cladoceran and geochemical dataset 


\section{Cladocera}

Thirty-seven species of Cladocera were found, among which 26 taxa occurred with a maximum abundance of $>2 \%$ in at least one sample (Fig. 4b). Pelagic cladocerans (e.g. Bosmina longirostris and B. coregoni) were abundant in the whole profile. Those that inhabit profundal sediments and macrophytes, however, occurred as well. Most of the species encountered are attributed to macrophyte and macrophyte/ sediment habitats, but none exceeded $10 \%$ abundance. Taxa associated with the sediment play a relatively minor role $(1.8 \%$ mean). In zone SUR-C1 $(6253 \pm 94-939 \pm 55 \mathrm{BC})$, pelagic species such as Bosmina longirostris and B. coregoni were predominant. Other taxa show a patchy occurrence and other habitat groups are also represented to a small extent. Distinct changes occurred with the beginning of zone SUR-C2 (939 \pm 55 BC-AD $166 \pm 44)$, when $B$. longirostris exceeded $50 \%$ abundance and $B$. coregoni disappeared almost completely. Moreover, Daphnia longispina disappeared after $773 \pm 55 \mathrm{BC}$ and Leptodora kindtii, which was not present before, occurred episodically since that time. Zone SUR-C3 (AD $166 \pm 44-1392 \pm 38$ ) is characterized by reappearance of B. coregoni (up to $14.7 \%$ ) and almost constant, low presence of Chydorus sphaericus $(0.3 \%$ mean). The species Leydigia leydigi, typical of the sediment habitat, appeared twice, at AD $262 \pm 44$ and $1180 \pm 38$. In zone SUR-C4 (since AD $1392 \pm 38$ ) distinct shifts occurred among the pelagic species and some taxa disappeared completely, i.e. B. longispina, Allonella exigua, Chydorus sphaericus cael., Leydigia acanthoceroides and Leydigia leydigi.

Geochemistry and stable isotopes

Five zones were distinguished using selected sediment components and elemental chemistry (Fig. 4c). In the bottom section (SUR-G1, $6253 \pm 94-2533 \pm 68$ BC), geochemical variables show relatively constant values. Some components, however, increase (TOC and BSi) or decrease (TIC) slightly. More prominent fluctuations are observed in MM (1.7-22.7\%, maximum at $4042 \pm 75 \mathrm{BC}$ ) and the $\mathrm{Fe} / \mathrm{Mn}$ ratio, which peaked at $3650 \pm 71 \mathrm{BC}$. A rapid increase in $\mathrm{Fe} / \mathrm{Mn}$ after $2610 \pm 68 \mathrm{BC}$ marks the transition to zone SURG2 $(2533 \pm 68-571 \pm 53 \mathrm{BC})$, in which organic components continued their trends, but stable isotopes remained relatively unchanged. The geochemical record in the interval from $571 \pm 53 \mathrm{BC}$ to $\mathrm{AD}$ $1557 \pm 36$ (SUR-G3) is characterized by instability of lacustrine processes, as seen by peaks in BSi and $\delta^{15} \mathrm{~N}$, the latter exhibiting a maximum of 5.4\%o at $65 \pm 46$ $\mathrm{BC}$, and pronounced variability of $\mathrm{Fe} / \mathrm{Mn}$. Lowest values of $\delta^{15} \mathrm{~N}(-0.2 \%$ ) occurred between $\mathrm{AD}$ $1557 \pm 36$ and $1770 \pm 30$ (SUR-G4). In this zone, only TOC/TN ratio and TIC were stable. The youngest zone SUR-G5, since AD $1770 \pm 30$, is characterized by a reduction in TIC (minimum of $1.86 \%$ ) and Fe/Mn at the beginning, and enrichment in MM (up to 52.9\% at $\mathrm{AD} 1879 \pm 18$ ), accompanied by highest values of $\delta^{13} \mathrm{C}_{\text {org }}$, which reach $-29 \%$ at AD $1825 \pm 28$.

Multi-proxy data integration

Arboreal pollen (AP) and four NAP groups reflect catchment vegetation transformation, related specifically to human activities such as settlements, deforestation and agriculture. Growing human influence is observed over the last 3000 years (Fig. 5). The combined diatom, cladoceran, sedimentological and geochemical datasets illustrate that lacustrine processes respond to environmental changes in the watershed. Distinct changes in the lacustrine conditions, namely episodes of higher trophic state in a previously oligotrophic lake, occurred since ca. 1500 BC. These initial changes were followed by minor changes in cladoceran assemblages, such as an increasing trend in pelagic taxa, and a decrease in macrophyte-related taxa, as well as in geochemical changes, especially in PC2 and PC3. A second episode of change was detected by the appearance of acidophilous diatoms around AD 1300, followed by a spread of eutrophic taxa, disappearance of sedimentrelated cladocerans and geochemical shifts. In the last ca. 180 years, lacustrine conditions changed dramatically, mainly in terms of trophic state, geochemical composition and structure of sediments.

The first RDA axis is significant and explains $32.8 \%$ of the total variance ( $p=0.001)$. The explanatory variable that best explains the total variance in lacustrine variables is AP $(30.9 \%)$. The NAP groups also explain some of this variance, but to a much smaller degree ( $<4 \%$ each group). An RDA triplot indicates that TIC, oligotrophic and indifferent diatoms are correlated with AP, while MM, eutrophic diatoms and $\delta^{13} \mathrm{C}_{\mathrm{org}}$ are negatively correlated with $\mathrm{AP}$ 

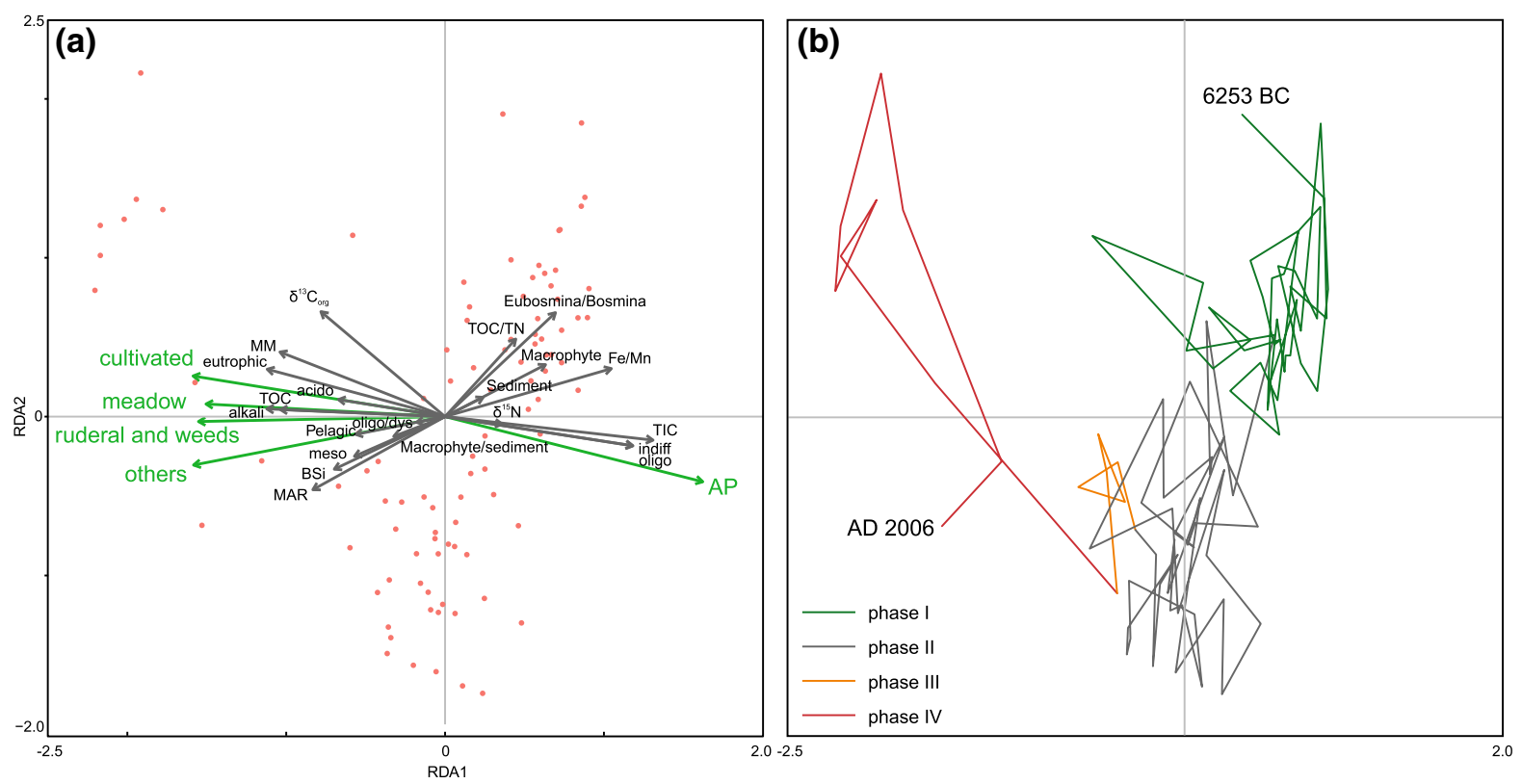

Fig. 6 a Redundancy analysis (RDA) triplot for samples (dots), in which pollen groups are explanatory variables, whereas lacustrine proxies are response variables. b RDA scores showing changes between the lacustrine phases

(Fig. 6a). On the other hand, TOC and alkaliphilous diatoms are correlated with meadows and acidophilous diatoms with fields (cultivated NAP). The sequence was divided into four lacustrine phases, and the unique character of the youngest phase is related mainly to human impact (Fig. 6b).

\section{Discussion}

The integrated data distinguished four main phases of development of Lake Szurpiły over the past 8200 years (Figs. 5, 6). Overall, lake conditions were responses to changes in the catchment. The two older lacustrine phase transitions occurred at the borders of pollen subzones, and the onset of the youngest lacustrine phase (IV) coincides with the beginning of pollen zone SUR-P4.

Phase I $(6253 \pm 94-939 \pm 55$ BC $)$

The oldest phase corresponds to pollen zone SUR-P1 and subzone SUR-P2a $(6253 \pm 94-939 \pm 55$ BC) (Fig. 5), which covers the Meso-/Neolithic (until 1800 $\mathrm{BC}$ ) and the beginning of the Bronze Age.

Pollen indicators of human impact are at an extremely low level, with pollen of cultivated plants never exceeding $0.3 \%$. The first Plantago lanceolata pollen grains, which indicate presence of pastures in the vicinity of the lake, were found in a sample dated to $1557 \pm 60 \mathrm{BC}$, relatively late compared to other sites in the region, e.g. Lakes Linówek (ca. 2050 BC; Gałka et al. 2014) and Wigry (ca. 2461 BC; Kupryjanowicz and Jurochnik 2009). Rye cultivation was confirmed for NE Polish sites by the first occurrence of Secale cereale pollen dating to $1300 \mathrm{BC}$ (Wacnik et al. 2012). In Lake Amalvas, the closest site to Lake Szurpiły ( $\sim 60 \mathrm{~km}$ to the NE), a continuous $S$. cereale pollen curve began at AD 650-860 (Juodagalvis and Balakauskas 2012), but farther north, a single grain yielded a radiocarbon age of AD 85-250 (Grikpedis and Matuzevičiūtè 2016). Such discrepancies may result from single grain occurrences, which do not necessarily indicate local cultivation. Also, unfavorable catchment morphology and low population density could have led to real differences between agricultural histories for sites located far from one another. Moreover, dating uncertainties and differences in sampling resolution may account for such discrepancies.

The multiple limnological proxies from the earliest phase of the studied sequence reflect a deep, oligotrophic lake and no evidence of significant human impact (Figs. 5, 6). Sedimentation occurred under 
relatively stable conditions, with constant low nutrient input (PC3) and only slightly varying delivery of terrigenous matter from the catchment. Periodic or seasonal anoxia in hypolimnetic water is indicated by low values of $\delta^{13} \mathrm{C}_{\mathrm{org}}$ and high Fe/Mn (Fig. 4c), which can be interpreted as resulting from microbial and/or methanogenic biomass (Heyng et al. 2012). Human impact increased slowly at the end of this phase, which coincides with the age of the oldest anthropogenic colluvium in the Suwałki region (Smolska and Szwarczewski 2008).

Phase II $(939 \pm 55$ BC-AD $1392 \pm 38)$

The second phase recorded in the lake sediments corresponds to pollen subzone SUR-P2b and SURP3a-b (until AD $1392 \pm 38$ ), which lasted from the Bronze Age to historic times. It includes the period of Yatvingian culture, which built a stronghold near Lakes Szurpiły, Kluczysko and Jeglówek (Figs. 1, 7). Phase II was a period of destabilization and increasing human activities, in terms of environmental change.

The abundance of human pollen indicators increased. The most distinct forest clearance occurred ca. AD 1000-1100. Settlers preferred hilly moraines surrounded by boggy areas, for strategic reasons. Settlements at the end of the Bronze Age and at the beginning of the Iron Age, however, were not permanent and often occupied seasonally (Engel and Sobczak 2012). Baltic tribes settled in the second half of the 1st millennium BC. Yatvings arrived in the 9th century AD. Engel and Sobczak (2017) suggest that agriculture and fishing only met the basic needs of local communities. Appearance of the large cladoceran Leptodora kindtii may indicate lower predation pressure from fish, a consequence of intensified fishing. Local settlements started intensive forest clearance, to obtain timber for building material and fuel, which is confirmed by a decrease in AP (Figs. 3, 5). The Yatvings took steps to defend themselves, first by locating their stronghold between lakes, by building ramparts and watchtowers, and even modifying the lake water levels. The oldest remains of stone and wooden ramparts are dated to AD 800-1000 (Engel et al. 2009). Engel and Sobczak (2017) suggest that the artificial channel that connects Lakes Kluczysko and Szurpiły was used for damming and flooding, depending on circumstances.

Medieval times are well known for the 'holy wars'. The Yatvingian stronghold at Lake Szurpiły was conquered by the Teutonic Order in AD 1283 (Fig. 7). Nevertheless, resettlements lasted several decades, prior to the tribal emptiness that characterized the period after the Baltic Crusades. There is no evidence of forest disturbance in the 15th century (high AP, no pollen of cultivated plants), in contrast to the increase in human indicators detected in Lake Linówek since AD 1400 (Gałka et al. 2014).

A general rise in abundance of eutrophic Stephanodiscus species and mesotrophic Asterionella formosa
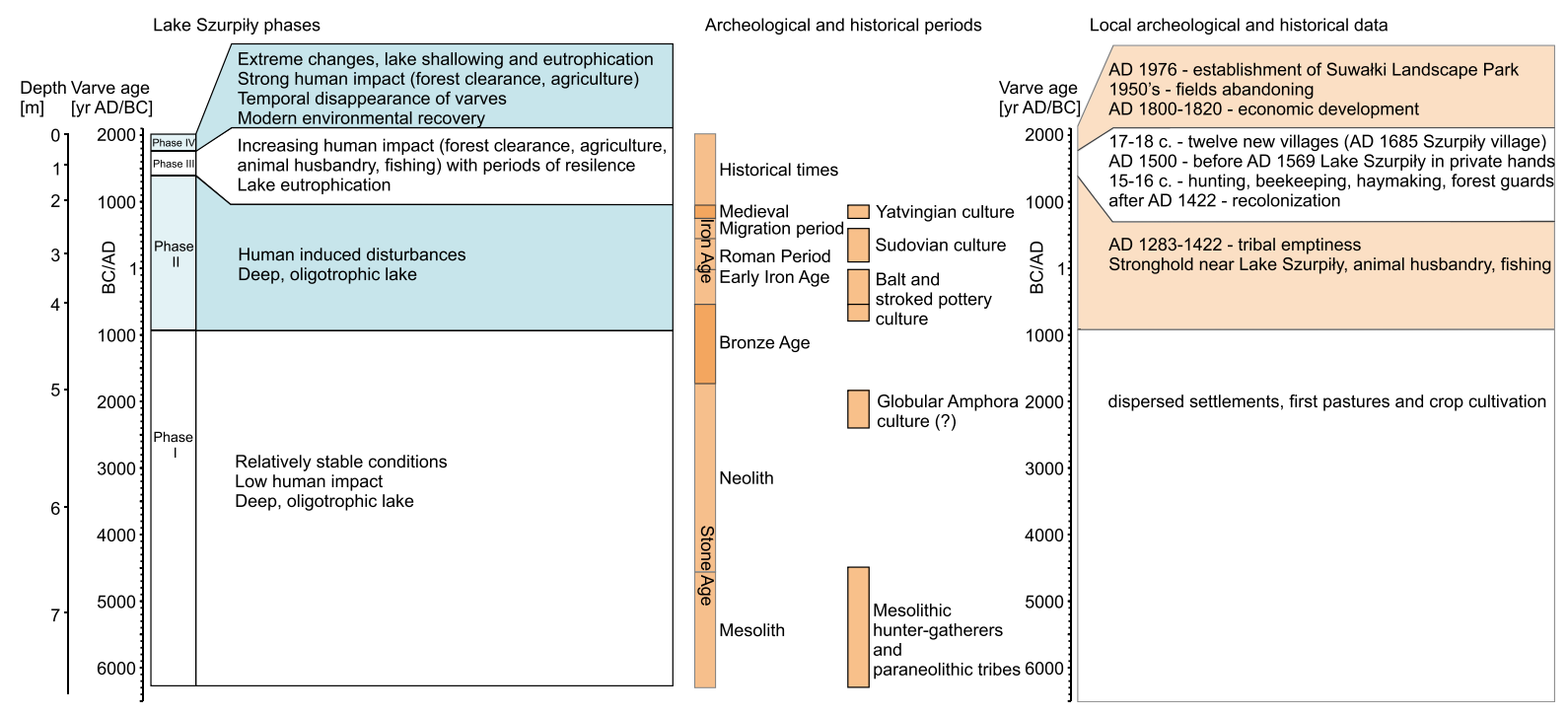

Fig. 7 Summary diagram of lake phases in relation to human activities in Lake Szurpiły and its catchment 
indicates a change from an oligotrophic to a mesotrophic lake, which may be related to human activities (Battarbee et al. 2012; Hall and Smol 2010). A shift in $\mathrm{Fe} / \mathrm{Mn}$ values around $600 \mathrm{BC}$, however, suggests greater concentrations of oxygen in deep waters (Fig. 4c). A similar pattern was observed at Lake Belau and linked to human impact, in particular to increased landscape openness and soil erosion (Dreibrodt and Wiethold 2015). Increased MAR in Lake Szurpiły between AD 1100 and 1300 coincides with peak sediment accumulations in Lake Jaczno, located $\sim 5 \mathrm{~km}$ to the north (Butz et al. 2017). Our results highlight human-induced disturbances in the catchment as a key factor driving increased landscape openness, and higher nutrient (PC3) and terrestrial $\mathrm{OM}$ input, which stimulated growth in the plankton community, contributed to greater MAR, and resulted in thicker spring-summer laminae, reflected by a shift in light/dark ratio (Figs. 2, 5).

Phase III (AD $1392 \pm 38-1770 \pm 30)$

The third phase of lake evolution coincides with pollen subzone SUR-P3c (AD $1392 \pm 38-1770 \pm 30$ ). It was a short period related to recolonization of the study area after a period of depopulation.

Abundant spruce (Picea abies) produces soil litter containing humic acids, which may have provoked lowering $\mathrm{pH}$ of the lake water, revealed by the appearance of acidophilous diatom taxa around $\mathrm{AD}$ 1400. Puusepp and Kangur (2010) presented a similar interpretation of the record from Lake Ķūži in Central Latvia. Spruce was growing in the catchment of Lake Szurpiły before, with the highest contribution of Picea pollen between 1600 and 1000 BC. It is possible, however, that human activity was relatively low at that time, and soil erosion was limited by dense forest. On the other hand, effects of historic peat exploitation should also be considered. Drainage of a peat bog south of the lake could have been an alternative or additional source of acidic input.

Forest clearance and soil erosion increased at the beginning of this phase and remained at high levels (Fig. 5), which indicates stabilized settlements and agricultural use of the fields. The beginning of this phase coincides with the re-cultivation of Secale cereale. The Grand Duchy of Lithuania began to recolonize the area, however initial human activities were limited to hunting, beekeeping and hay production (Antoniewicz 1965). Increased forest clearance may have been associated with new iron ore smelters, which were built in the 16th century. Large numbers of micro-charcoal particles in this phase indicate extensive fires and deforestation (Kupryjanowicz pers. commun.). In Lake Żabińskie, a micro-charcoal peak was dated to AD 1610-1640 and interpreted as human-induced burning of forests or related to iron smelting in the Weggorzewo region (Wacnik et al. 2016).

Even though 12 new villages were founded in the vicinity of Lake Szurpiły in the 17th and 18th centuries (Fig. 7), lake response was weak and inconsistent. The species composition of the cladoceran community was transformed and suggests that fishing or limited water transparency resulted in weaker fish predation pressure on zooplankton (Jeppesen et al. 2002; Szeroczyńska 2016). Slowly progressing eutrophication is confirmed by increased abundance of Chydorus sphaericus (Fig. 4b). Nevertheless, other lines of evidence indicate a rather low nutrient supply (Fig. 5). The $\delta^{15} \mathrm{~N}$ values close to $0 \%$ around $\mathrm{AD}$ 1750 could indicate a large contribution to the sediment organic matter from $\mathrm{N}$-fixing cyanobacterial biomass, caused perhaps by a decline in $\mathrm{N}$ availability. The apparent contradiction between biological proxies of trophic status and nitrogen isotope ratios can be explained by the fact that increased phosphorus input into the lake could have provoked nitrogen fixation by lowering the $\mathrm{N}: \mathrm{P}$ ratio in the water column (Vitousek et al. 2002). Lower MAR, varve thickness and light/dark ratio were likely a consequence of limited terrestrial input from the catchment area. Despite human presence, phase III reveals relative stability before the onset of large transformations.

Phase IV (AD $1770 \pm$ 30-2006)

The beginning of this phase indicates the onset of unprecedented human impact. This period relates to pollen zone SUR-P4 and is characterized by the most remarkable changes in both the catchment and lake proper (Figs. 5, 6b). The end of phase IV shows the most recent environmental recovery of the lake and its surrounding catchment.

A simultaneous rapid decline of AP and rise in human-related NAP reflect large-scale forest clearance accompanied by expansion of arable land 
(Fig. 5). As the glacial moraines surrounding Lake Szurpiły are prone to slope erosion, it is likely that widespread deforestation and agricultural activities promoted flux of terrestrial matter to the lake. This interpretation may be supported by the negative correlation between AP and MM (Fig. 6a), and the fluctuating position of phase IV (Fig. 6b). Synchronous shifts in $\delta^{13} \mathrm{C}_{\text {org }}$, lithogenic elements and pollen reflect varying inputs of allochthonous matter to the sediment related to forest clearance and soil erosion. At the beginning of this phase, MAR increased and MM peaked at $\mathrm{AD} 1879 \pm 18$, which coincides with the onset of intense erosion recorded in Lake Żabińskie (Bonk et al. 2016). According to historic sources, iron ore smelting in the Suwałki region since the second half of the 17 th century could have been the reason for land clearance (Ambrosiewicz 2009). Deforestation was probably selective. For instance, until the middle of the 18th century, spruce timber had a low market value, and thus was expanded relative to other tree species thereafter (Czerwiński 1973). Pine began to be cut for the cellulose industry and paper production in the middle of the 19th century. Nonetheless, some forest fluctuations could have been natural, e.g. the decrease of Picea could have been caused by the European spruce bark beetle (Ips typographus), and black arches (nun moths) (Lymantria monacha). There is evidence that those insects invaded forests in East Prussia between AD 1853 and 1862, then arrived farther east in the Suwałki Lake District and Lithuania.

Further eutrophication or even short-term dystrophication took place at the beginning of phase IV (Fig. 5). Stephanodiscus species and Cyclostephanos dubius are indicators of eutrophy (Hall and Smol 2010; Punning and Puusepp 2007). Eutrophic, alkaliphilous diatom species, mainly Stephanodiscus, reached their highest abundance in Lake Szurpiły. At the same time, sediment-related cladoceran habitats were reduced, which may have been related to increased turbidity caused by plankton blooms. As a consequence, there were relatively more pelagic species.

Short-term $\mathrm{pH}$ changes could have been caused by peat exploitation or peat bog drainage. Peat exploitation in NE Poland was common, but abandoned in the mid-20th century, when the area was depopulated significantly. Even though we do not have any historical information about peat exploitation from the Lake Szurpiły region, the peat bog to the south, which serves as a periodic inflow, could have been the source of humic acid entering the lake.

The TOC/TN ratio shows a positive shift and thus a decreasing contribution of algal versus land-plant organic matter to the sediments (Meyers 1994), coinciding with increased $\delta^{13} \mathrm{C}_{\text {org }}$ values, reflecting the increased input of terrigenous organic matter that was relatively enriched in ${ }^{13} \mathrm{C}$ compared to autochthonously produced organic matter. Agriculture in the Lake Szurpiły watershed intensified the transport of terrigenous organic and minerogenic matter to the lake. The more open landscape around the lake caused higher wind exposure and better mixing of the water column. This coincided with the temporal disappearance of laminations in the sediments.

The role of eutrophication for the preservation of varves has been discussed in many studies (Dreibrodt and Wiethold 2015; Lotter et al. 1997). In some cases, eutrophication was a key factor triggering laminated structure for the first time, whereas in others, it enhanced preservation of existing varves (Dreibrodt and Wiethold 2015). In Lake Szurpiły, this could account for the reappearance of varves in AD 1998. Comparison of limnological measurements in Lake Szurpiły from AD 1979, 1983/4 and 2007-2010 suggested that in the 1990s, lacustrine productivity increased and anoxia became stronger, causing deposition of annually laminated sediments. On the other hand, our results indicate that the environment transformed by humans is recovering. This recovery may be related to the establishment of Suwałki Landscape Park and the socio-economic situation in northeast Poland (Fig. 7). As farmers became older and farming proved to be economically difficult, fields were abandoned. Many local inhabitants turned to agro-tourism or emigrated to work in larger towns. Moreover, the environmental effects of changes in land tenure laws and liquidation of state agricultural farms in Poland in AD 1991 are clearly visible in other lacustrine records (Karpińska-Kołaczek et al. 2014; Wacnik et al. 2016).

\section{Conclusions}

The aim of this study was to infer anthropogenic environmental impacts during the last 8200 years using the varved sediment record from Lake Szurpiły, northeast Poland. An interdisciplinary, multi-proxy 
approach enabled us to track the catchment evolution, shaped mainly by human activities, and observe lake responses to these variations.

Natural fluctuations and insignificant anthropogenic influence prevailed until $939 \pm 55 \mathrm{BC}$, when the region was sparsely populated and sedimentation was relatively stable. Balt settlements had low impact because of their low numbers and seasonal character. Later, human impacts became more important, mainly a consequence of deforestation connected to the prosperity of the Yatvings around AD 1000-1100. Between AD $1392 \pm 38$ and $1770 \pm 30$ (phase III), stabilization of permanent settlements and the economy resulted in reduction of terrestrial input and decreased MAR. The most pronounced human impacts on the catchment, and rapid response of lacustrine processes, occurred since AD $1770 \pm 30$. Only in the last 20 years has the system experienced environmental recovery, along with reappearance of varved sediments. Absence of annual laminations provides evidence that certain thresholds in depositional conditions were surpassed. Discrepancies between records from Lake Szurpiły and other sites in the region may be a consequence of dating problems, different temporal sampling resolution between study sites, or differences in settlement history, all of which emphasize the importance of good time control and interdisciplinary cooperation. This study demonstrated that relatively deep lakes in regions that have apparently sustained low human impact, can nevertheless record anthropogenic influences.

Acknowledgements This study was supported by a Polish Ministry of Science and Higher Education Grant to M. Kinder (NN306 009337). It is a contribution to the bilateral scientific program "Northern Polish Lake Research" (NORPOLAR), a Polish-German research initiative carried out between the Universities of Bremen and Gdańsk and funded by the German Research Foundation and the Polish Ministry of Science and Higher Education. We thank Christian Ohlendorf for fieldwork and XRF scanning and Dirk Enters for thin section preparation. We also acknowledge the support and cooperation of Suwałki Landscape Park.

Open Access This article is distributed under the terms of the Creative Commons Attribution 4.0 International License (http:// creativecommons.org/licenses/by/4.0/), which permits unrestricted use, distribution, and reproduction in any medium, provided you give appropriate credit to the original author(s) and the source, provide a link to the Creative Commons license, and indicate if changes were made.

\section{References}

Ambrosiewicz M (2009) Obecność człowieka nad Wigrami. In: Rutkowski J, Krzysztofiak L (eds) Jezioro Wigry. Historia jeziora w świetle badań geologicznych i paleoekologicznych. Stowarzyszenie Człowiek i Przyroda, Suwałki, pp 241-255

Antoniewicz J (ed) (1965) Studia i materiały do dziejów Suwalszczyzny: praca zbiorowa, 4. Państwowe Wydawnictwo Naukowe, Białystok

Augustsson A, Gaillard MJ, Pelota P, Mazier F, Bergbäck B, Saarinen T (2013) Effects of land use and climate change on erosion intensity and sediment geochemistry at Lake Lehmilampi, Finland. Holocene 23:1247-1259

Bajkiewicz-Grabowska E (1994) Charakterystyka fizycznogeograficzna i hydrograficzna Suwalskiego Parku Krajobrazowego. Zeszyty Naukowe Komitetu PAN Człowiek i Środowisko 7:15-31

Battarbee RW (1986) Diatom analysis. In: Berglund BE (ed) Handbook of holocene palaeoecology and palaeohydrology. Wiley, Chichester, pp 527-570

Battarbee RW, Anderson NJ, Bennion H, Simpson GL (2012) Combining limnological and palaeolimnological data to disentangle the effects of nutrient pollution and climate change on lake ecosystems: problems and potential. Freshw Biol 57:2091-2106

Ber A (2000) Plejstocen Polski północno-wschodniej w nawiązaniu do głębszego podłoża i obszarów sąsiednich. Prace Państwowego Instytutu Geologicznego, Warszawa, p 170

Berglund BE (2003) Human impact and climate changessynchronous events and a causal link? Quat Int 105:7-12

Bitner-Wróblewska A, Brzeziński W, Kasprzycka M (eds) (2016) Yatving archaeology: past research, new perspectives. Państwowe Muzeum Archeologiczne, Warszawa

Bjerring R, Becares E, Declerck S, Gross EM, Hansson LA, Kairesalo T, Nykänen M, Halkiewicz A, Kornijów R, Conde-Porcuna JM, Seferlis M, Nõges T, Moss B, Lildal Amsinck S, Vad Odgaard B, Jeppesen E (2009) Subfossil Cladocera in relation to contemporary environmental variables in 54 Pan-European lakes. Freshw Biol 54:2401-2417

Bonk A, Kinder M, Enters D, Grosjean M, Meyer-Jacob C, Tylmann W (2016) Sedimentological and geochemical responses of Lake Żabińskie (north-eastern Poland) to erosion changes during the last millennium. J Paleolimnol 56:239-252

Butz C, Grosjean M, Goslar T, Tylmann W (2017) Hyperspectral imaging of sedimentary bacterial pigments: a 1700-year history of meromixis from varved Lake Jaczno, northeast Poland. J Paleolimnol 58:57-72

Cohen AS (2003) Paleolimnology: the history and evolution of lake systems. Oxford University Press, New York

Czerwiński A (1973) Lasy dębowo-świerkowe Działu Północnego. In: Czeczuga B (ed) Przyroda Białostocczyzny i jej ochrona, vol 19. Prace Białostockiego Towarzystwa Naukowego, Warszawa, pp 135-203

Dean WE (1999) The carbon cycle and biogeochemical dynamics in lake sediments. J Paleolimnol 21:375-393 
Dearing JA (2006) Climate-human-environment interactions: resolving our past. Clim Past 2:187-203

Dreibrodt S, Wiethold J (2015) Lake Belau and its catchment (northern Germany): a key archive of environmental history in northern central Europe since the onset of agriculture. Holocene 25:296-322

Dubois N, Saulnier-Talbot É, Mills K, Gell P, Battarbee P, Bennion H, Gomes DF, Gregory-Eaves I, Humane S, Kattel G, Jenny J-P, Langdon P, Massaferro J, McGowan S, Mikomägi A, Thi Minh Ngoc N, Sandaruwan Ratnayake A, Reid M, Rose N, Saros J, Schillereff D, Tolotti M, Valero-Garcés B (2018) First human impacts and responses of aquatic systems: a review of palaeolimnological records from around the world. Anthr Rev 5:28-68

Engel M, Sobczak C (2012) Nie tylko archeologia. Interdyscyplinarne badania wielokulturowego zespołu osadniczego w Szurpiłach na Suwalszczyźnie. Pruthenia 7:137-157

Engel M, Sobczak C (2017) Rola cieków i zbiorników wodnych w życiu pradziejowych i wczesnohistorycznych społeczności Suwalszczyzny. In: Tanajewska M, Swierubska T (eds) Materiały konferencyjne Stan i Ochrona Wód Suwalskiego Parku Krajobrazowego. Wigry, Poland 15-16 September 2016. Stowarzyszenie Miłośników Suwalskiego Parku Krajobrazowego "Kraina Hańczy”, Malesowizna-Turtul, pp 81-89

Engel M, Okulicz-Kozaryn J, Sobczak C (2009) Warowna siedziba jaćwieskiego nobila Шюрпы. Architektura obronna kompleksu osadniczego w Szurpiłach. In: BitnerWróblewska A, Iwanowska G (eds) Bałtowie i ich sąsiedzi. Państwowe Muzeum Archeologiczne, Warszawa, pp 517-544

Faegri K, Iversen J (1989) Textbook of pollen analysis. Blackwell Scientific Publications, Copenhagen

Frey DG (1986) Cladocera analysis. In: Berglund BE (ed) Handbook of holocene palaeoecology and palaeohydrology. Wiley, Chichester

Gałka M, Tobolski K, Zawisza E, Goslar T (2014) Postglacial history of vegetation, human activity and lake-level changes at Jezioro Linówek in northeast Poland, based on multiproxy data. Veg Hist Archeobot 23:123-152

Górniak A, Reszczyński K, Siwak P, Świerubska T (2007) Suwalski Park Krajobrazowy. In: Fałtynowicz W (ed) Kraina Hańczy. Stowarzyszenie Miłośników Suwalskiego Parku Krajobrazowego, Turtul, pp 67-73

Grikpedis M, Matuzevičiūte GM (2016) The beginnings of rye (Secale cereale) cultivation in the East Baltics. Veg Hist Archaeobot 25:601-610

Hall RI, Smol JP (2010) Diatoms as indicators of lake eutrophication. In: Stoermer EF, Smol JP (eds) The diatoms: applications for the environmental and earth sciences. Cambridge University Press, Cambridge, pp 122-151

Hammer $\varnothing$, Harper DAT (2006) Paleontological data analysis. Blackwell Publishing, Oxford

Heiri O, Lotter AF, Lemcke G (2001) Loss on ignition as a method for estimating organic and carbonate content in sediments: reproducibility and comparability of results. J Paleolimnol 25:101-110

Heyng A, Mayr C, Lücke A, Striewski B, Wastegård S, Wissel H (2012) Environmental changes in northern New Zealand since the Middle Holocene inferred from stable isotope records $\left(\mathrm{d}^{15} \mathrm{~N}, \mathrm{~d}^{13} \mathrm{C}\right)$ of Lake Pupuke. J Paleolimnol 48:351-361

Hofmann G (1994) Aufwuchs-Diatomeen in Seen und ihre Eignung als Indikatoren der Trophie. Bibliotheca Diatomologica. J Cramer 30:241

Hustedt F (1956) Kieselalgen (Diatomeen). Kosmos, Gesellschaft der Naturfreunde, Stuttgart

Jeppesen E, Jensen JP, Amsinck S, Landkildehus F, Lauridsen T, Mitchell SF (2002) Reconstructing the historical changes in Daphnia mean size and planktivorous fish abundance in lakes from the size of Daphnia ephippia in the sediment. J Paleolimnol 27:133-143

Juggins S (2017) rioja: analysis of quaternary science data, $\mathrm{R}$ package version (0.9-15.1). http://cran.r-project.org/ package $=$ rioja

Juodagalvis V, Balakauskas L (2012) Gamtos ir kultūros raidos bruožai Amalvo ir Žuvinto tarpežeryje. Liet Archeol 38:53-106

Karpińska-Kołaczek M, Kołaczek P, Stachowicz-Rybka R (2014) Pathways of woodland succession under low human impact during the last 13,000 years in northeastern Poland. Quat Int 328:196-212

Kinder M, Tylmann W, Enters D, Piotrowska N, Poręba G, Zolitschka B (2013) Construction and validation of calendar-year time scale for annually laminated sedimentsan example from Lake Szurpiły (NE Poland). GFF 135:248-257

Kupryjanowicz M, Jurochnik A (2009) Pollen record of postglacial vegetation changes as contained in bottom deposits of Wigry Lake. In: Rutkowski J, Krzysztofiak L (eds) Wigry lake. History of the lake in the light of geological and paleoecological studies. Stowarzyszenie "Człowiek i Przyroda", Suwałki, pp 181-198

Lorenc H (ed) (2005) Atlas klimatu Polski. Instytut Meteorologii i Gospodarki Wodnej, Warszawa

Lotter AF, Sturm M, Teranes JL, Wehrli B (1997) Varve formation since 1885 and high-resolution varve analyses in hypertrophic Baldeggersee (Switzerland). Aquat Sci 59:304-325

Messerli B, Grosjean M, Hofer T, Nunez L, Pfister C (2000) From nature-dominated to human-dominated environmental changes. Quat Sci Rev 19:459-479

Meyers PA (1994) Preservation of elemental and isotopic source identification of sedimentary organic matter. Chem Geol 114:289-302

Mills K, Schillereff D, Saulnier-Talbot É, Gell P, Anderson NJ, Arnaud F, Dong X, Jones M, McGowan S, Massaferro J, Moorhouse H, Perez L, Ryves DB (2017) Deciphering long-term records of natural variability and human impact as recorded in lake sediments: a palaeolimnological puzzle. Wiley Interdiscip Rev Water 4:e1195

Müller PJ, Schneider R (1993) An automated leaching method for the determination of opal in sediments and particulate matter. Deep Sea Res 40:425-444

Oksanen J, Blanchet FG, Kindt R, Legendre P, Minchin PR, O'Hara RB, Simpson GL, Solymos P, Stevens MHH, Wagner H (2018) vegan: community ecology package. R package version 2.5-2. http://CRAN.R-project.org/ package $=$ vegan 
Poraj-Górska AI, Żarczyński MJ, Ahrens A, Enters D, Weisbrodt D, Tylmann W (2017) Impact of historical land use changes on lacustrine sedimentation recorded in varved sediments of Lake Jaczno, northeastern Poland. Catena 153:182-193

Punning J-M, Puusepp L (2007) Diatom assemblages in sediments of Lake Juusa, Southern Estonia with an assessment of their habitat. Hydrobiologia 586:27-41

Puusepp L, Kangur M (2010) Linking diatom community dynamics to terrestrial vegetation changes: a palaeolimnological case study of Lake Kūži, Vidzeme Heights (Central Latvia). Estonian J Ecol 59:259-280

R Core Team (2013) R: a language and environment for statistical computing. R Foundation for Statistical Computing, Vienna, Austria. http://www.R-project.org/

Round FE (1981) The diatom genus Stephanodiscus: an electron-microscopic view of the classical species. Arch Protistenk 124:455-470

Simpson GL (2017) ggvegan: 'ggplot2' plots for the 'vegan' package. $\mathrm{R}$ package version 0.0-9. https://github.com/ gavinsimpson/ggvegan

Smolska E, Szwarczewski P (2008) Zróżnicowanie wiekowe pokryw stokowych jako efekt niesynchronicznego zasiedlania Pojezierza Suwalskiego i Sejneńskiego. In: Wacnik A, Madeyska E (eds) Polska północno-wschodnia w holocenie. Człowiek i środowisko. W. Szafer Institute of Botany, Polish Academy of Sciences, Kraków, pp 157-168

Stanton T, Snowball I, Zillén L, Wastegård S (2010) Validating a Swedish varve chronology using radiocarbon, palaeomagnetic secular variation, lead pollution history and statistical correlation. Quat Geochronol 5:611-624

Stivrins N, Brown A, Veski S, Ratniece V, Heinsalu A, Austin J, Liiv M, Cerina A (2016) Palaeoenvironmental evidence for the impact of the crusades on the local and regional environment of medieval (13th-16th century) northern Latvia, eastern Baltic. Holocene 26:61-69
Stockmarr J (1971) Tablets with spores used in absolute pollen analysis. Pollen Spores 13:615-621

Szal M, Kupryjanowicz M, Tylmann W, Piotrowska N (2017) Was it "terra desolata"? Conquering and colonizing the medieval Prussian wilderness in the context of climate change. Holocene 27:465-480

Szeroczyńska K (2016) Long term subfossil Cladocera record from the partly varved sediment of Lake Tiefer See (NE Germany). Adv Oceanogr Limnol 7:184-196

Tylmann W, Zolitschka B, Enters D, Ohlendorf C (2013) Laminated lake sediments in northeast Poland: distribution, preconditions for formation and potential for paleoenvironmental investigation. J Paleolimnol 50:487-503

Vitousek PM, Cassman K, Cleveland C, Crews T, Field CB, Grimm NB, Howarth RW, Marino R, Martinelli L, Rastetter EB, Sprent JI (2002) Towards an ecological understanding of biological nitrogen fixation. Biogeochemistry $57: 1-45$

Wacnik A, Goslar T, Czernik J (2012) Vegetation changes caused by agricultural societies in the Great Mazurian Lake District. Acta Palaeobot 52:59-104

Wacnik A, Tylmann W, Bonk A, Goslar T, Enters D, MeyerJacob C, Grosjean M (2016) Determining the responses of vegetation to natural processes and human impacts in north-eastern Poland during the last millennium: combined pollen, geochemical and historical data. Veg Hist Archaeobot 25:479-498

Zolitschka B, Francus P, Ojala AE, Schimmelmann A (2015) Varves in lake sediments-a review. Quat Sci Rev $117: 1-41$

Publisher's Note Springer Nature remains neutral with regard to jurisdictional claims in published maps and institutional affiliations. 